\title{
Mobile Communications of the Needy and Poor: Affordability Indicators, European Data, Social Tariffs
}

\author{
Louis-Francois $\mathrm{Pau}^{1}$, Pedro Puga ${ }^{2}$, Hong $\mathrm{Chen}^{3}$, and Zviad Kirtava ${ }^{4}$ \\ ${ }^{1}$ Copenhagen Business School \& Rotterdam School of Management \\ ${ }^{2}$ CIES-IUL Portuguese Center for Research and studies in Sociology \\ ${ }^{3}$ Huawei Technologies Europe \\ ${ }^{4}$ Partners for Health NGO / National Information Learning Centre, Tbilisi, Georgia \\ lpau@nypost.dk, pedro.puga@iscte.pt, hchen77@gmail.com, \\ zkirtava@nilc.org.ge
}

\begin{abstract}
This section summarizes the data and information collected across Europe and beyond, inside the COST 605 Action (2008-2011), and can be relevant for separate analysis, research and regulations about the mobile communications costs of poor and needy groups. Miscellaneous social and macro-economic data on the needy and their mobile communications usage in five European countries are presented. It also contains the specification of a new indicator whereby the affordability of mobile communications for poor and needy can be established, and the corresponding results for 7 countries in 2006 and 2010. The indicator is the "poor's purchasing power parity (PPP) in wireless minutes per month", based on reported data collected on the distribution amongst poor and needy groups in Georgia and France. An Appendix gives some data sources for the countries where data were collected.
\end{abstract}

Keywords: e-Inclusion, Mobile communications, Social tariffs, Affordability, Indicators.

\section{Mobile Communications of the Needy and Poor}

This section summarizes the data and information collected across Europe and beyond, inside the COST 605 Action (2008-2011), and can be relevant for separate analysis, research and regulations about the mobile communications costs of poor and needy groups. The derived analyses and research or regulations are not surveyed in this section, and this section is not structured as a research article but as a fact collection. An Appendix gives some national data sources for the countries where data were collected. A list of references gives pointers to related data collection, methodology or analysis work and also contains the references to the papers produced by the COST 605 Action on communications for the needy [1, 3, 8, 9, 14, 15].

The methodology whereby these data have been collected and aggregated has been to identify and verify relevant, but often inconsistent and unpublished data sources (government or NGO reports, regulator reports, survey reports, UN and ITU statistics, operator data, verbal reports). Mobile tariff and pricing data have used operator data, 
field work, regulator reports (Europe and Georgia) (Appendix 1), as well as tariff surveys $[5,6])$. The reader is thus warned about the fact that, for lack of extensive research budgets and means, the data assembled here could not always be validated from multiple sources, although all of them seem to represent the consensus estimates of operational people working with, or on, poor and needy.

It should be stressed that while there has been extensive data collection in developed as well as developing countries $[1,4]$ on demographics, revenues, housing of poor and needy, there has been almost none on the telecommunications practices and spending of these groups, or on specific telecommunications services (even on public telephony). There has been theoretical analysis rooted in income distribution [11] the applicability of which hedges on data collection efforts like this one. This section furthermore focuses on public wireless communications, which represent by far the widest relative adoption in that group among combined fixed telephony, broadband, Internet and wireless services [13]. In terms of geographical coverage, the focus is on the much neglected European poor and needy, as well as those in Georgia, representing a population on European fringes and part of the Council of Europe [10]. Whereas OECD has defined baskets of telecommunications services with variants in 2002, 2006 and 2010, the poor /needy groups for basic practical reasons and affordability still prioritize plain voice communications the highest for social inclusion, work, and other specific needs. While this fact may evolve over time, focus is here solely on wireless voice and the corresponding usage in view of the affordability constraints of these groups.

World Development Indicators Database (World Bank group) methodology for mobile pricing is using a monthly basket of 25 "standard" calls + 30 SMS. One of OECD's baskets includes per year: 1680 outgoing calls $(2952 \mathrm{~min})+600 \mathrm{SMS}+12$ MMS. ITU's ICT Price Basket (IPB) index and its depiction of ICT affordability is a composite affordability measure based on three sub-baskets - fixed telephone, mobile cellular and fixed broadband Internet services - and computed as a percentage of average Gross National Income (GNI) per capita. ICT spending correspond to less than 5\% of GNI per capita in much of Europe and Asia and the Pacific's high income economies, as well as in the US and Canada; but for sure, for poor and needy, which have chosen to be connected (prepaid or post-paid), the ratio is much larger, making the issue much more critical. The ITU IPB studies also reveal a close link between the affordability of ICT services and national income levels: people in high-income countries spend relatively little for ICT services, while those in the world's poorest countries spend relatively more, both in absolute terms (e.g., mobile minute cost) and in relative terms (as a share of disposable income).

\section{Who Are the Poor and Needy}

This section aggregates, or segments, data about the following groups in the population [13]:

- Poor, defined as such under minimum household subsistence revenue limit [4]

- Homeless (still approx. $30 \%$ have work)

- Unemployed getting unemployment benefits, searching jobs, but under minimum household subsistence limit 
- Unemployed after expiration of unemployment and social benefits

- Isolated individuals of all ages, often subject to a social / medical / penal fracture (e.g., $39 \%$ of age group 79-83 years in France)

- Migrant workers who have or find very short term employment away from domicile (incl. seasonal workers in, e.g., tourism and agriculture) [2]

- Elderly alone with home care on low pensions under subsistence limit (e.g. $89 \%$ of 79-83 years age group in France)

- Displaced populations due to war, national disasters or climate change effects

- Some immigrants (approx. 10 million immigrant workers in Europe) [2, 5]

- Many categories of disabled persons and some categories of sick persons

According to Eurostat this heterogeneous group represented in 2004: 73 Million people in EU (16\% of the population), 2 Million people in EFTA countries, and 160 Million people in the geographical areas part of Council of Europe [7]. In the above segmentation, the household subsistence revenue limit is usually defined as by UN at $60 \%$ of national GNI average.

\subsection{European Macrodata on the "Needy" and Their Mobile Communications Usage or "Social Mobile Tariffs"}

Some COST 605 Action participating countries have contributed to a survey on the above subject (Denmark, France, Georgia, Netherlands, and Portugal). The focus was on needy / poor people (see subsection 2.1), especially on

- social parameters, demographics, employment, income,

- measured or assumed mobile communications service usage and spending, and

- cases of individuals or groups of needy people's as to mobile communications usage and spending (from individual interviews, secondary information sources).

Table 1 addresses data collected so far across 5 EU countries mostly for 2006: Netherlands, Portugal, France, United Kingdom, and Denmark. It should be noted that definitions are not always identical and that collection methods and sources may be inconsistent. It should also be noted that in general the data are from many different sources thus not always with same year or basis. Some data were collected on the basis of field surveys and are not found in other sources. The Monetary unit was Euros for calibration purposes (except UK where GPB/EUR exchange rate fluctuations prevented that calibration). When a definition cannot be used uniformly across countries, due to different legislations, or data collection methods, indications are given in the Table as to different interpretations; especially UK has different estimation concepts (see Appendix).

The goal of the survey is to provide the basis for the establishment of social wireless tariff bundles made affordable to the needy and subsidized or not by operators and/or regulators (using revenue from universal service obligation laws, where applicable) [5, 10]. Another goal is to help European regulator and the Commission prepare for directives with the same goal across the EU $[5,6,7]$. As the ubiquity of wireless communications has a high social value and impact, this study is justified beyond general analyses of universal access to broadband services. 


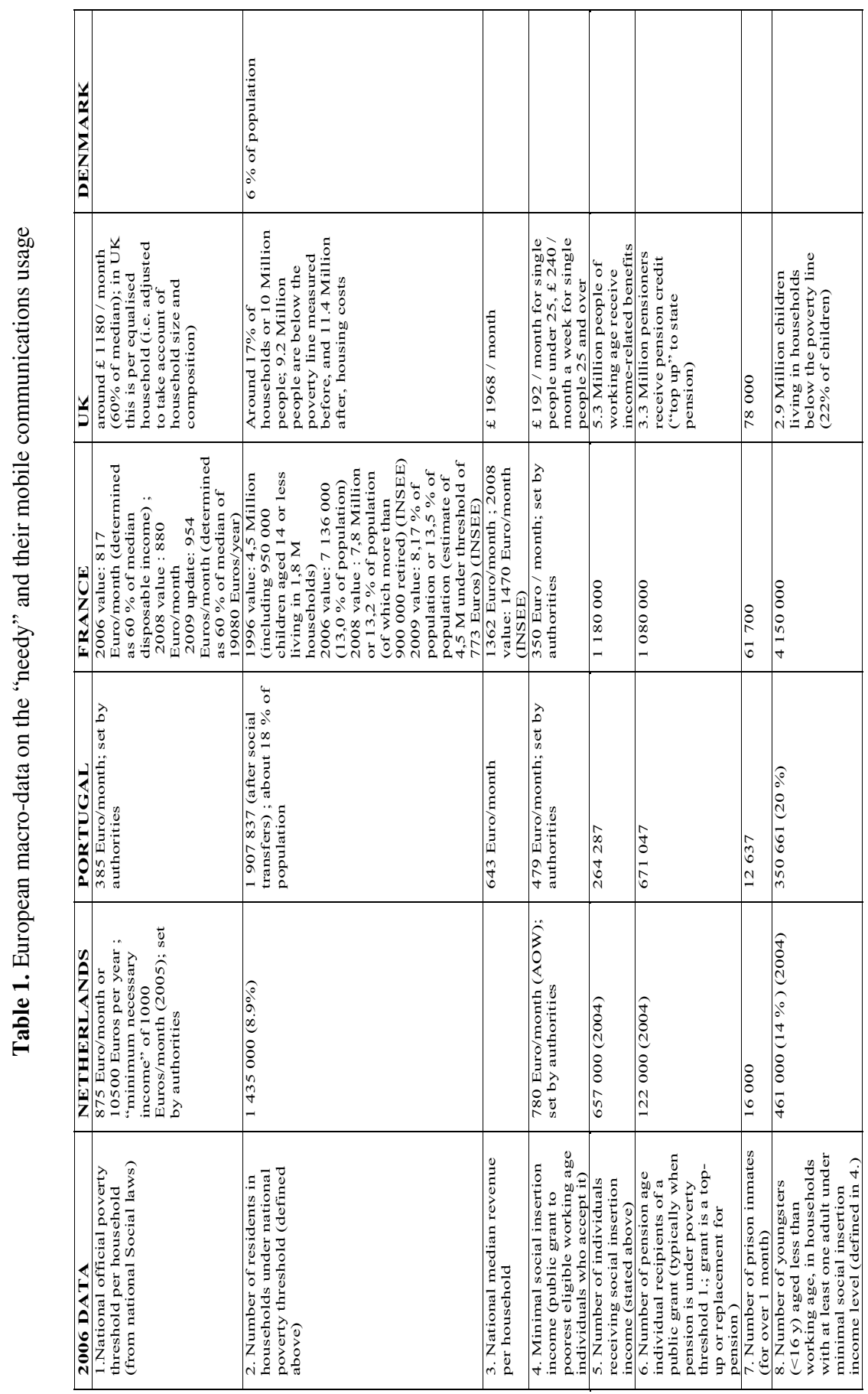




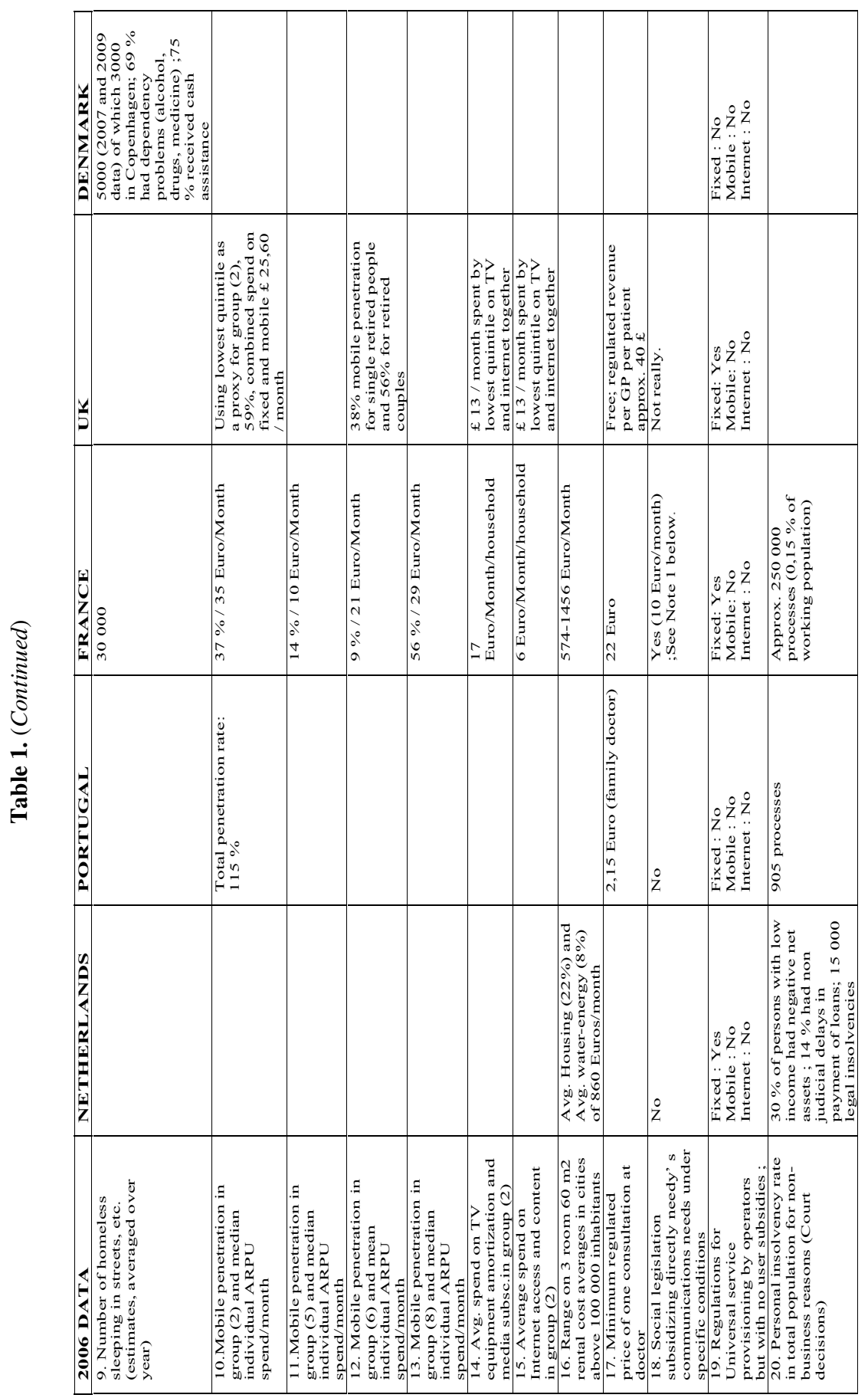




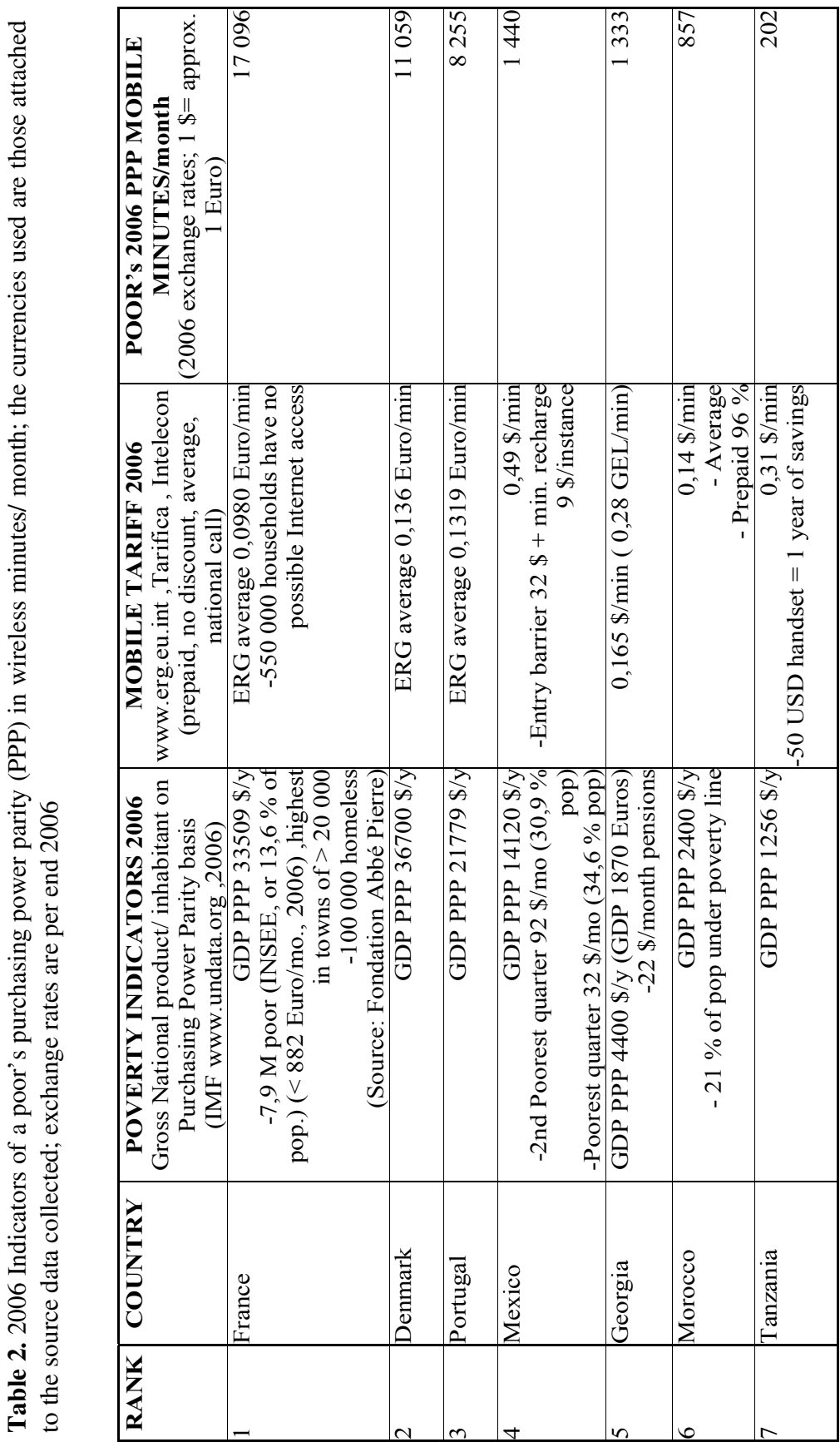




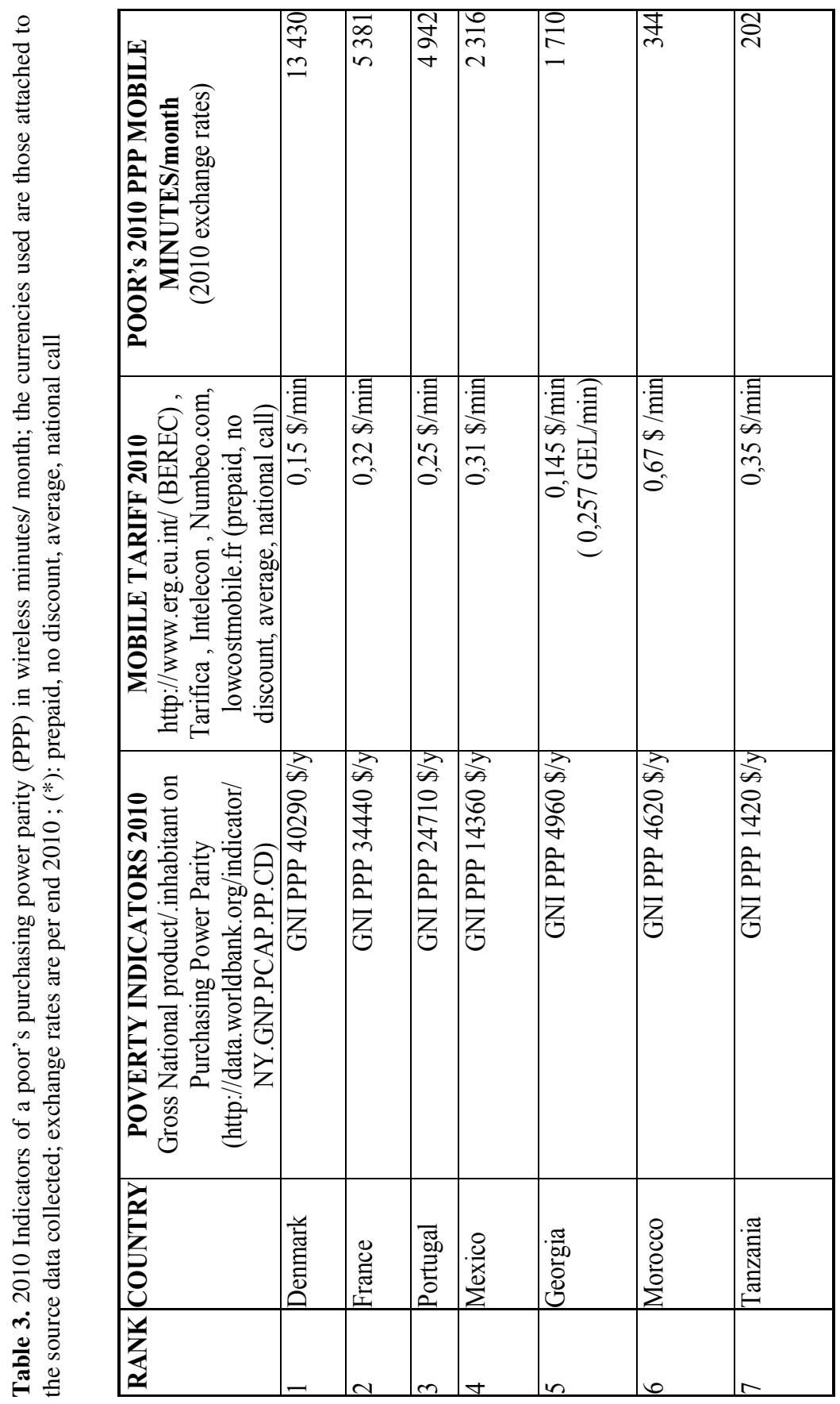




\subsection{The Needy's Purchasing Power in Mobile Minutes and the "Mobile Communications Divide"}

As an attempt to compare by a single indicator the affordability of mobile communications for poor and needy groups across countries [13, 14], we present the following indicator: “A poor's purchasing power parity (PPP) in wireless minutes per month". PPP is defined as: the ratio of UN purchasing power GNI PPP (Gross National product per Inhabitant on Purchasing power parity) (in one basis currency), multiplied by 0.6 to reflect the normal definition of the poverty limit, divided by the average price (in same basis currency) of one wireless voice minute (fully loaded to caller) as established by the national regulator, and further divided by 12 months. This wireless voice minute is assumed prepaid, with no terminals cost share, for a call to a national number, excluding discounts and plans. It shows, in simple words, how many minutes of wireless voice a poor would get per month if all his purchasing income that month was spent prepaid on talking in the same country over a wireless operator.

Table 2, gives 2006 data for 7 countries of which three EU countries addressed in detail in subsection 2.2, and it was elaborated for the first time by the authors in Lisbon in 2008. Table 3 below gives an update for 2010. These tables show:

- For each of them, very significant ranges of values: in 2006 from 202 minutes/month (Tanzania) to 284 hours/month (France), and in 2010 from 202 minutes/month to 223 hours/month (Denmark); this represents the "mobile communications divide";

- Fairly stable rankings in the small country sample, but that the index for some countries has fallen significantly (France, Morocco, Portugal), while it has risen for some others (Mexico, Denmark);

- The average mobile tariff dynamics over time do not correlate with the evolution of the PPP GNI (Gross National product/inhabitant on purchasing power parity basis). This is despite regulatory interventions, competition, reductions in interconnection rates (European Union), within-operator's network vs. outgoing call differentiation (Europe), specific tariff plans or brands for social groups (for "unemployed" like in Spain, for "poor and needy" like in France, "youth" everywhere), and/or occasional ceilings on price per mobile minute (as in Georgia: 0,24 GEL/min since 2011).

Some consultancies adopt non-transparent rank determination methods, like the case of INFORMA Telecoms \& Media and World Development Business "awarding" 3rd place to Georgia (among 186 countries researched) for having one of the most expensive mobile rates in the world (Jan 2010). Most consultancies studying eInclusion just do not include wireless access, but only Internet access [5].

Example of "Social Mobile tariff" (France): A France Telecom / Orange offer called "RSA ("Revenu de solidarité active") special tariff plan", available in Metropolitan France, and linked to RSA legislation and recognition. It includes 40 minutes of calls to landlines and mobiles plus 40 SMS, for $€ 10$ per month, without a contract. It is available to all RSA beneficiaries, whether or not they are already Orange customers. This plan allows unused minutes and SMS to be carried forward. 
Orange customers eligible for the "RSA special tariff plan" but already under contract can move onto this plan at no cost and with no commitment. Customers from other operators can keep their existing mobile number. Orange is also selling a range of cheap mobile phones in its stores starting from €39. RSA beneficiaries only can either buy second-hand handsets from $€ 10$ or benefit from the offer without buying a mobile" Orange already offers several benefits to promote spending power in France:

- unlimited SMS service or $10 \%$ reduction on some offers for young people under 26 years old;

- $10 \%$ reduction on "initial" fixed rate packages for those over 60 years old;

- 20\% reduction on the "click" offer for jobseekers and large families.

Furthermore, a €20 social triple play offer (telephone, TV and broadband Internet) is being prepared

\subsection{Distribution by Groups of the Poor and Needy and Effects of Falling Affordability}

This subsection provides the distribution of poor and needy for Georgia and France by narrower groups as those identified in subsection 2.1 and expands this analysis for household's general affordability constraints in Denmark. Table 4 gives for France the distribution by categories of the poor under the poverty level; it also gives the percentage in each category with e.g. for 2009 a maximum of $34,7 \%$ for unemployed and $30,3 \%$ for "other inactives". Table 5 contains the distribution for Georgia for an estimated total population of needy and poor of 4, 4 Million inhabitants. The Danish data [12] confirm falling affordability due to falling disposable private consumption and fast rise in tariffs and address the structural analysis of affordability data for households. The growing overexposure of households towards real estate and consumer credit, has lead the credit ratio (balance of liabilities/ net disposable income after taxes) to raise to $300 \%$, but assets (incl. Pension assets and free shares in real estate) have grown faster with a ratio of $460 \%$ (2010). Inside liabilities, real estate mortgage debt represents about $75 \%$ and other liabilities $25 \%$. The combination of high liabilities, illiquid assets and falling real estate prices, has increased the risk from loss of income/job and has exposed the households to interest rate increases; a $3 \%$ increase in interest rates at the end of 2010 lead to interest payments reaching avg. $30 \%$ of net income. Due to parallel increases in energy and transportation costs, the private consumption ratio (disposable income net of taxes and energy) in 2010 was only $92 \%$ of the 2007 value.

As median mobile tariffs in Denmark have over the past 10 years grown at approx. twice the inflation rate (Q3:2011: 3\%), and as a 2 year postpaid subscription plans can be assimilated to a 2 year mortgage obligation, their share inside net disposable income has approx. doubled; unless short term unsecured consumer loan credits are used to cover this increase, the research question is which expense items had to be reduced to accommodate mobile communications inside falling private consumption. 
Table 4. Distribution of the poor and needy by groups, for metropolitan France (2008) (Source INSEE 30/8/2011)

\begin{tabular}{|c|c|c|c|}
\hline $\mathbf{2 0 0 8}$ & $\begin{array}{c}\text { Thousands of } \\
\text { poor persons }\end{array}$ & $\begin{array}{c}\text { Poverty ratio } \\
(\mathbf{\%})\end{array}$ & $\begin{array}{c}\text { Poverty intensity } \\
(\mathbf{\%})\end{array}$ \\
\hline $\begin{array}{c}\text { Active persons 18 } \\
\text { Years or above }\end{array}$ & 2635 & $9,5 \%$ & $20,6 \%$ \\
\hline $\begin{array}{c}\text { Active in a job, of } \\
\text { which }\end{array}$ & 1863 & $7,3 \%$ & $18,2 \%$ \\
\hline -Salaried & 1445 & $6,3 \%$ & $15,8 \%$ \\
\hline $\begin{array}{c}\text {-Independent } \\
\text { workers }\end{array}$ & 418 & $15,3 \%$ & $29,1 \%$ \\
\hline $\begin{array}{c}\text { Unemployed } \\
\text { or above }\end{array}$ & 772 & $35,8 \%$ & $27,2 \%$ \\
\hline $\begin{array}{c}\text { Inactive aged 18 y } \\
\text {-Students }\end{array}$ & 2873 & $15,1 \%$ & $17,2 \%$ \\
\hline -Retired persons & 1283 & $9,9 \%$ & $13,1 \%$ \\
\hline -Other inactive & 1266 & $29,3 \%$ & $21,4 \%$ \\
\hline $\begin{array}{c}\text { Children < 18 } \\
\text { years }\end{array}$ & 2328 & $17,3 \%$ & $18,3 \%$ \\
\hline Total population & 7836 & $13,0 \%$ & $18,5 \%$ \\
\hline
\end{tabular}

Table 5. Distribution of poor and needy in Georgia (2008); Source: National Statistics office of Georgia www.geostat.ge

\begin{tabular}{|c|c|c|}
\hline GEORGIA 2010 Categories & \% of total needy & Inhabitants \\
\hline Refugees/IDP's & $6.1 \%$ & 270000 \\
\hline Unemployed & $16.4 \%$ & 315000 \\
\hline Pensioners & $14.9 \%$ & 656000 \\
\hline Disabled & $3.1 \%$ & 137000 \\
\hline Impoverished & $8.4 \%$ & 370000 \\
\hline Near poverty level & $14.3 \%$ & 630000 \\
\hline Prisoners & $0.4 \%$ & 18659 \\
\hline Unspecified & $45.4 \%$ & 1997000 \\
\hline TOTAL & $100 \%$ & 4394000 \\
\hline
\end{tabular}




\section{Summary and Conclusions}

The present data analysis in several countries provides key data to analyze the affordability of mobile communications for the poor and needy. It also presents several simple indicators to be used for policy making and tariffing. Mobile social tariffs are also described to reduce the mobile communications divide, which is at least as important as the Internet digital divide.

Open Access. This article is distributed under the terms of the Creative Commons Attribution Noncommercial License which permits any noncommercial use, distribution, and reproduction in any medium, provided the original author(s) and source are credited.

\section{References}

1. Avila, A.: Underdeveloped ICT areas in Sub-Saharan Africa. Informatica Economică Journal 13(2) (2009)

2. Calenda, D. (ed.): Migrants, ethnic minorities and ICT IN Europe - National Scenario: an overview of six countries (Germany, Spain, Italy, France, The Czech Republic, The Netherlands), BRIDGE-IT Thematic network (2011)

3. Concepción Garcia-Jimenez, M., Gomez-Barroso, J.-L.: Universal Service in a Broader Perspective: The European Digital Divide. Informatica Economică Journal 13(2) (2009), http: / / www.revistaie.ase.ro/current.html

4. Dilip Potnis, D.: Cell-phone-enabled empowerment of women earning less than $\$ 1 /$ day. IEEE Technology and Society Magazine, 39-45 (Summer 2011)

5. Empirica (for EU), Benchmarking in a Policy Perspective: Report no 5 on elnclusion. Gesellschaft für Kommunikations- und Technologie-forschung mBH, Bonn (2006)

6. European Commission, Report on Telecoms Price Developments from 1998 to 2010 (2011)

7. European Commission, Digital agenda assembly, 16-17/6/2011, Report from workshop 2009 Access and digital ability: building a barrier-free digital society

8. Falch, M., Henten, A.: Achieving Universal Access to Broadband. Informatica Economică Journal 13(2) (2009)

9. Kirtava, Z.: Mobile Operator Supports Refugees and Disabled in Georgia. Informatica Economică Journal 13(2) (2009)

10. Kirtava, Z.: Mobile Operators For Low-Income Population - Case of Georgia: Special Tariffs - To Be or Not To Be? In: Proceedings of COST 298 Project Conference on Broadband Society "The Good, The Bad and The Challenging - The User and the Future of Information and Communication Technologies", Copenhagen, May 13-15, vol. II, pp. 930-939 (2009)

11. Milne, C.: Affordability of basic telephone service: an income distribution approach. Telecommunications Policy 24, 907-927 (2000)

12. Nationalbanken, Finansiel stabilitet, pp. 70-78 and Kvartalsoversigt, Q2-Del 1, pp. 39-44 (2011) (in Danish)

13. Pau, L.-F.: Mobile service Affordability for the Needy, Addiction, and ICT policy implications. In: Proc. 7th Intl. Conf. on Mobile Business, Barcelona, July 7-8 (2008)

14. Pau, L.-F.: Enabling mobile communications for the needy: affordability methodology, and approaches to re-qualify universal service measures. Informatica Economică Journal 13(2) (2009)

15. Puga, P., Cardoso, G., Espanha, R., Mendonça, S.: Telecommunications for the Needy: How needed are they? Informatica Economică Journal 13(2) (2009) 


\section{Appendix: Data Sources}

1. Europe: BERC (European regulator's group) www.erg.eu.int

2. United Nations: UN data www.undata.org

3. Denmark: Nationalt forskningscenter for velfaerd www.sfi.dk

4. France: French regulator ARCEP www.arcep.fr; Fondation Abbé Pierre http://www.fondation-abbe-pierre.fr/; Fondation de France http://www.fdf.org/; Petits frères des pauvres http://www.petitsfreres.asso.fr; INSEE www.insee.fr, Observatoire national de la pauvreté et de l'exclusion sociale (ONPES) http://www.travail-solidarite.gouv.fr/web/observatoire-national-pauvreteexclusion-sociale; INSEE study «Revenus fixes et sociaux 2006-2009, 30/8/2011; Ministère de l'emploi et de la solidarité http://www.interieur.gouv.fr/misill/sections/liens/ministere-emploi-solidarite/view France Telecom social tariff: http://www.francetelecom.com\%2fen_EN\%2fpress\%2fpress_releases\%2fcp09051 2en.jsp; Handicap International http://www.handicap-international.fr/; French Parliament decision on social tariffs of 09 June 2008 : http://www.assembleenationale.fr/13/cra/2007-2008/187.asp

5. Georgia: Georgia National Communication Commission (GNCC) Annual reports 2005-2010 (in Georgian) www.gncc.ge ; Georgia Social Service Agency (in 2008: Social Subsidies Agency) database http://ssa.gov.ge ; National Statistics Office of Georgia www.geostat.ge

6. Netherlands: National Bureau of statistics www.cbs.nl/en-GB/

7. Portugal: DGERT (Direcção-Geral do Emprego e das Relações de Trabalho Ministry of Solidarity and Social Security): www.dgert.mtss.gov.pt/

The Portuguese Social Security System: www2.seg-social.pt; INE - Statistics Portugal: www.ine.pt Deco - Portuguese Association for the Consumer Defense: www.deco.proteste.pt; ICP- ANACOM: www.anacom.pt

8. Spain: Telefonica social tariff: http://www.telefonica.es\%2fon\%2fio\%2fes\%2fteayudamos\%2fhome.html

9. UK : National poverty

http://www.statistics.gov.uk/downloads/theme_social/Family_Spending_2007/Fa milySpending2008_web.pdf and http://www.dwp.gov.uk/asd/frs/2003_04/tables/pdf/3_8.pdf; Social insertion income www.dwp.gov.uk; Prisoners

http://www.homeoffice.gov.uk/rds/pdfs06/hosb1106.pdf; Expected spending on mobile phones for different household types

http://www.minimumincomestandard.org; Attitudinal research by Ofcom among low income groups http://ofcom.org.uk/research/tce/ce07/annex4.pdf; Ofcom research into mobile take-up and spend http://ofcom.org.uk/research/tce/ce07/research07.pdf; Affordability report 2006 http://www.regulateonline.org 